\title{
Non-Squamous Epithelial Cell Count
}

National Cancer Institute

\section{Source}

National Cancer Institute. Non-Squamous Epithelial Cell Count. NCI Thesaurus. Code C135413.

The determination of the amount of non-squamous epithelial cells present in a sample. 